\title{
Reversible Liver Steatosis Induced by Chemotherapy of Mixed-phenotype Acute Leukemia
}

\author{
Atsujiro Nishioka ${ }^{1}$, Yasushi Kubota ${ }^{1,2}$, Eisaburo Sueoka ${ }^{2,3}$ and Shinya Kimura ${ }^{1}$
}

Key words: L-asparaginase, liver steatosis, mixed-phenotype acute leukemia, liver biopsy

(Intern Med 55: 1025-1026, 2016)

(DOI: 10.2169/internalmedicine.55.5685)
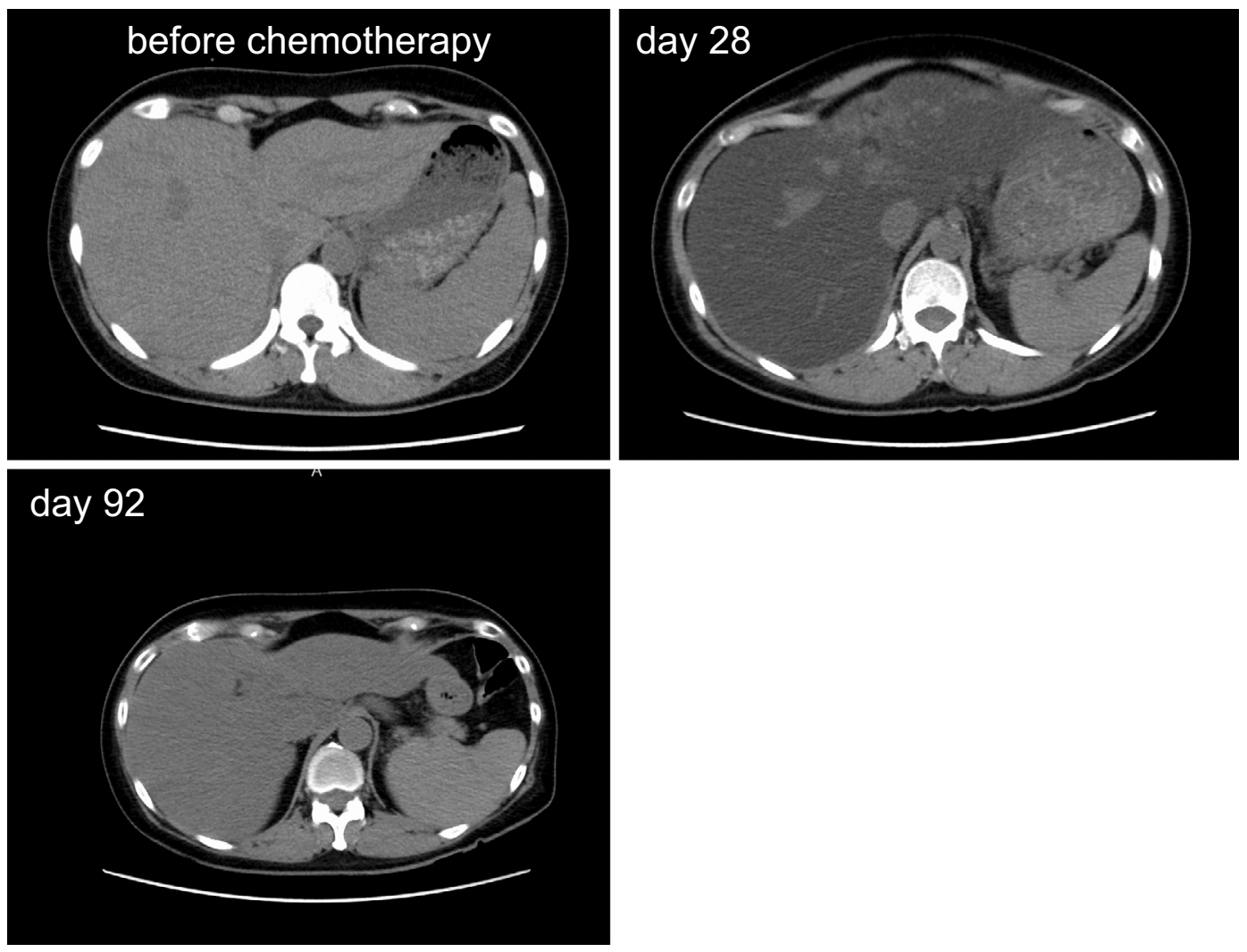

Picture 1.

A 49-year-old woman with mixed-phenotype acute leukemia received induction chemotherapy including cyclophosphamide $\left(1,200 \mathrm{mg} / \mathrm{m}^{2}\right.$ on day 1$)$, daunorubicin $\left(60 \mathrm{mg} / \mathrm{m}^{2}\right.$ on days $1-3)$, vincristine $\left(1.3 \mathrm{mg} / \mathrm{m}^{2}\right.$ on days $1,8,15$ and $22)$, Escherichia coli L-asparaginase $\left(5,000 \mathrm{U} / \mathrm{m}^{2}\right.$ on days 8 , $10,12,14,16,18,20$ and 22$)$, and prednisolone $\left(60 \mathrm{mg} / \mathrm{m}^{2}\right.$ on days 1-14). Laboratory evaluation at diagnosis revealed a marked elevation in liver enzyme levels (AST, 353 IU/L; ALT, $354 \mathrm{IU} / \mathrm{L}$; and T-bil, $1.1 \mathrm{mg} / \mathrm{dL}$ ), possibly due to hepatic involvement of leukemia. The liver enzyme levels improved; however, on day 19, after six injections of Lasparaginase, the liver enzyme levels suddenly re-elevated (AST, $191 \mathrm{IU} / \mathrm{L}$; ALT, $184 \mathrm{IU} / \mathrm{L}$; and T-Bil, $3.1 \mathrm{mg} / \mathrm{dL}$ ). Computed tomography (CT) showed diffuse low attenuation

\footnotetext{
${ }^{1}$ Division of Hematology, Respiratory Medicine and Oncology, Department of Internal Medicine, Faculty of Medicine, Saga University, Japan, ${ }^{2}$ Department of Transfusion Medicine, Saga University Hospital, Japan and ${ }^{3}$ Department of Clinical Laboratory Medicine, Faculty of Medicine, Saga University, Japan

Received for publication May 1, 2015; Accepted for publication July 29, 2015

Correspondence to Dr. Yasushi Kubota, kubotay@cc.saga-u.ac.jp
} 


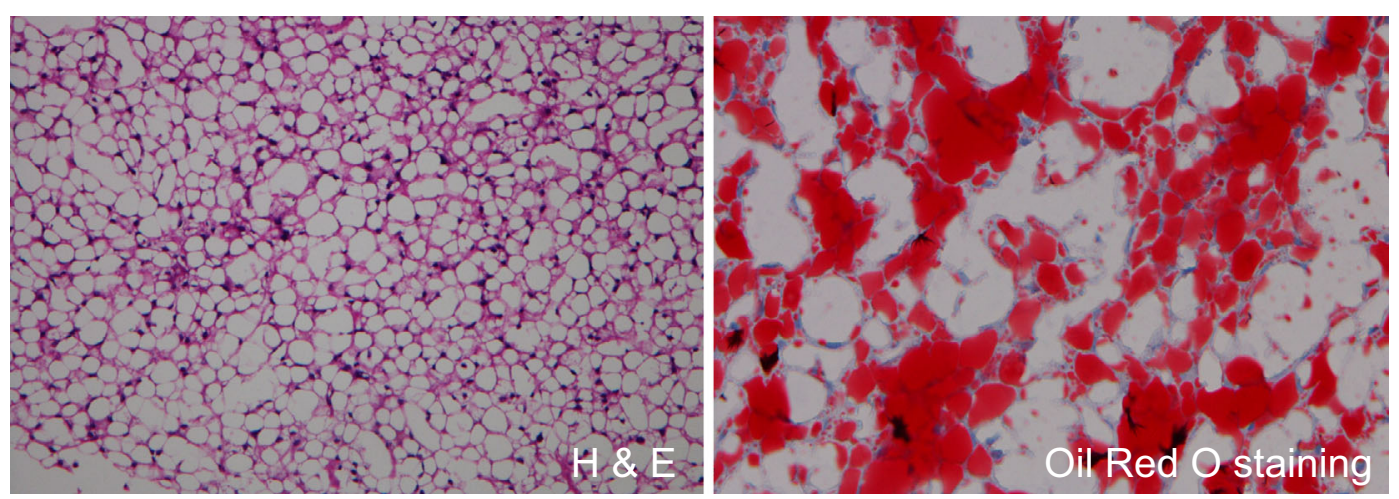

Picture 2.

of the liver (Picture 1). Chemotherapy was discontinued and a liver biopsy revealed severe diffuse steatosis involving $>90 \%$ of the hepatocytes (Picture 2). Induction chemotherapy was unsuccessful, and subsequent high-dose cytarabine was administered. The patient then underwent haploidentical reduced-intensity stem cell transplantation. She achieved complete chimerism and remission. The liver enzyme levels and the CT attenuation values of the liver also improved (Picture 1).

In the present case, all administered chemotherapeutic agents were candidates for potentially inducing severe steatosis. The increased incidence of $\mathrm{L}$-asparaginase-induced liver dysfunction has been reported when L-asparaginase is used in combination with vincristine and prednisolone (1). The severity of hepatic damage caused by chemotherapy including L-asparaginase is unpredictable (2). It is difficult to distinguish between leukemia infiltration of the liver and drug-induced hepatotoxicity. In this context, a liver biopsy is informative for the differential diagnosis.

\section{The authors state that they have no Conflict of Interest (COI).}

\section{Acknowledgement}

We thank Kazuo Wakayama for taking excellent pictures.

\section{References}

1. Woods WG, O'Leary M, Nesbit ME. Life-threatening neuropathy and hepatotoxicity in infants during induction therapy for acute lymphoblastic leukemia. J Pediatr 98: 642-645, 1981.

2. Sahoo S, Hart J. Histopathological features of L-asparaginaseinduced liver disease. Semin Liver Dis 23: 295-299, 2003.

(C) 2016 The Japanese Society of Internal Medicine http://www.naika.or.jp/imonline/index.html 